\title{
The Effectiveness of Commissioners Board Size And Audit Commitee Size on Risk Disclosure
}

\author{
Yubiharto $^{1 *}$, Walid Rudianti ${ }^{2}$ \\ ${ }^{1,2}$ STIE Taman Siswa Banjarnegara \\ *Correspondence email : yubiharto2016@gmail.com
}

\begin{abstract}
Abstrak. Penelitian bertujuan menganalisis efektivitas ukuran Dewan Komisaris dan ukuran Komite Audit terhadap pengungkapan risiko (studi empiris pada perusahaan pertambangan sub sektor tambang batu bara yang terdaftar di Bursa Efek Indonesia periode 2016-2018). Penelitian menggunakan sampel sebanyak 19 perusahaan pertambangan sub sektor tambang batu bara yang terdaftar di Bursa Efek Indonesia periode 2016-2018. Metode penelitian menggunakan regresi linier berganda dengan pendekatan data panel. Ukuran Dewan Komisaris berpengaruh positif dan signifikan terhadap pengungkapan risiko pada perusahaan pertambangan sub sektor tambang batu bara yang terdaftar di Bursa Efek Indonesia BEI periode $2016-2018$. Sementara itu, ukuran komite audit berpengaruh negatif dan signifikan terhadap pengungkapan risiko pada perusahaan pertambangan yang terdaftar di Bursa Efek Indoenesia BEI periode 2016-2018. Bagi investor atau calon investor dalam memutuskan berinvestasi sebaiknya memperhatikan ukuran Dewan Komisaris dan Komite Audit pada perusahaan.
\end{abstract}

Kata kunci : Pengungkapan Risiko, Ukuran Dewan Komisaris, Ukuran Komite Audit

\begin{abstract}
The purpose of this study is to analyse the effectiveness of the Commissioners Board size Audit Committee size on risk disclosure (empirical study on coal-mining sub-sector under mining sector companies listed on Indonesian Stock Exchange during the period of 2016-2018). The samples for this study are 19 companies under coal-mining sub-sector listed in Indonesian Stock Exchange during the period of 2016-2018. The methodology used in this study is multiple linear regression with data panel approach. Commissioners Board size has a positive and significant effect on risk disclosure in the companies under mining sector and coal-mining sub sector listed in IDX during the period of 2016-2018. Meanwhile, audit committee size has a negative and significant effect on risk disclosure in the companies under mining sector and coal-mining sub sector listed in IDX during the period of 2016-2018. It is advisable for investors and prospective investors to consider Commissioners Board size and Audit Committee size.
\end{abstract}

Keywords: Risk Disclosure, Commissioners Board Size, Audit Committee Size

\section{Introduction}

Risk is considered to be one of the factors that could be avoided in the business world. It is something that always present in any business. Risk itself could be related to some elements of uncertainty about something that might happen in the future that either results in gains or losses. One of the ways to reduce the probability of risks from happening is by implementing risk management actions. An example of implementation of risk management is risk disclosures done by companies that have gone public on Indonesian Stock Exchange (IDX) (Inggrid and Badjuri, 2018). Risk disclosure could be an important factor in financial reporting because it could give information on companies' risk management and how they could impact the future of the companies. Risk disclosure might also be an interest for stakeholders regarding any accounting scandals that happened in several companies that could make them doubt any financial information reported by the companies. It could also be used to help anticipate and resolve risks, reducing any information asymmetry, and help stakeholders to understand the risk profiles of the companies. If information on risks is not available in the annual report, it could weaken the accountability and transparency of the companies in the mind of the stakeholders because it could affect their judgement in predicting the future situations that the companies might face (Irawan, 2006).

The importance of risk disclosure has led regulatory bodies in Indonesia, called Ikatan Akuntan Indonesia (IAI), to issue rules and regulations that require any information on risks to be reported in the companies' annual report. As mentioned in Pernyataan Standard Akuntansi Keuangan (PSAK) No. 60 about Financial instruments: Disclosures, information that could be used by the users of financial reports to evaluate the types and degrees of risks from financial instruments must be disclosed. Such information disclosure could be in the form of qualitative disclosures and quantitative disclosures. In qualitative disclosures, entity is required to disclose how risks could surface, the aim, policy, and the process of risk management, as well as the method in measuring risks.

Another regulation on risk disclosure is Keputusan Ketua Badan Pengawas Pasar Modal dan Lembaga Keuangan (Bapepam LK) No: Kep-431/BL/2012 on obligation to submit annual report for entities or public companies. It was required for companies to present explanations on risks faced by the companies that could affect their going concern and the efforts that have been done to manage said risks. There are several factors that could affect 
risk disclosures, such as: Good Corporate Governance (GCG) and the company's characteristics. This paper will discuss further into the effect of GCG on the companies' risk disclosures based on two things; firstly, because GCG is needed to present information more broadly and more transparent, secondly, because some information on GCG in Indonesia is still quite left behind compared to other countries. Among other countries in ASEAN, only two companies in Indonesia were listed in 50 best companies in GCG practice in the event of ASEAN Corporate Governance Award 2015 (Primadhyta, 2019). GCG components that affect risk disclosures are managerial ownership, institutional ownership, public ownership, commissioners board, and audit committee. This study will use commissioners board size and audit committee size to measure GCG.

Commissioners board is an organisation within the company that supervise and advice the directors to ensure that the company is managed based on its functions and objectives (Sulistyaningsih and Gunawan, 2016). The role of commissioners board involves ensuring the implementation of companies' strategy, supervising management in administering the companies as well as obliging the practice of transparency which includes risk disclosures. A bigger size of commissioners board might improve the quality of supervisions and might prevent the occurrence of risk disclosure restrictions by the management of the company. Previous study done by Kencana and Lastanti (2018) stated that commissioners board size has a positive and significant impact on risk disclosures, while Barbara and Yulia (2017) concluded that commissioners board size has no effect on risk disclosure. Apart from commissioners board, to maintain the continuity and congruence of corporate governance mechanisms, there is a need for an audit committee. Audit committee helps the commissioners board with their tasks and functions (Utomo and Chariri, 2014). Based on their tasks and responsibilities, it could be concluded that the bigger the size of an audit committee, the better the supervision on risk disclosure information in their financial report.

Previous study by Tarantika and Solikhah (2019) stated that the company size has a positive and significant effect on risk disclosure. Contrary to the study done by Sulistyaningsih and Gunawan (2016), it concluded that the size of the company has no effect on risk disclosure. Mining companies were chosen as the object of this study for several reasons. Firstly, mining companies are considered to have high risks, such as: political risk, changing regulation, price, financial risk, operational risk, and capital project. Secondly, mining companies are companies that manage resources and hence their economical transactions involved many stakeholders. Such transactions in such companies usually create a number of high risks. Thirdly, there is still very limited research done on risk disclosures in mining companies.

\section{Method}

Purposive sampling was used in this study. It is a technique on determining research samples based on certain criteria. The reason purposive sampling was used as methodology was because not all samples have the criteria that has been set by the researcher. The criteria used in determining samples for this study are: 1) Mining companies under sub-sector coal mining that are listed in Indonesian Stock Exchange during the period of 2016-2018,2) Mining companies that have a full available data regarding the variables used in this study. From the two criteria, 19 samples of companies' data were collected for the period of 3 years. Therefore, there are 57 samples in total. There are two independent variables used in this study, Commissioners Board size and Audit Committee size, along with one dependent variable which is Risk Disclosure. Risk Disclosure was measure by using COSO framework. Based on the RMD issued by COSO, there are 108 items in Risk Management Disclosures (RMD) that covers eight dimensions, namely: internal environment, objective setting, event identification, risk assessment, risk response, control activities, information and communication, and lastly monitoring information on RMD from the annual report and company website (Rustiarini, 2012)

The board of commissioners is an organisation inside the company that is in charge of conducting general and special supervision based on the company charter, as well as giving advice for the directors (Sukrisno and Ardana, 2014). The commissioners board size was measured by using the number of members in the commissioners board. According to Tugiman (1995), audit committee is a group of people chosen by a higher-level group of people to conduct a certain function or to perform specific tasks, or a group of commissioners board members from the client's companies that are responsible to help auditors in maintaining their independency from the management. Audit committee size in this study is measured by using the number of members of audit committee in the company. The equation used in this study is as follows: $Y_{i t}=b_{o}+b_{1} X_{1 i t}+b_{2} X_{2 i t}++e_{i t}$

$\mathrm{Y}=$ Risk Disclosure $\mathrm{b}_{\mathrm{o}}=$ constant $\mathrm{b}_{1,2}=$ Regression coefficient of the independent variable; $\mathrm{X}_{1}=$ Commissioners Board Size; $\mathrm{X}_{2}=$ Audit Committee Size; $\mathrm{e}=$ error; $i=$ cross-section; $t=$ time-series

The data panel equation above was then estimated by using the approach model of common effect, fixed effect, and random effect, while in order to determine which model was suitable for this study, some tests were conducted, such as: Chow Test, Hausman Test, and LM Test (Ghozali, 2016). The next step is conducting classical assumption test against the regression model used. This was done to find out whether or not the regression model used 
in this study was suitable. The classic assumption test used consisted of several tests, namely: normality test, multicollinearity test, heteroscedasticity test, and auto-corellation test.

\section{Results And Discussions}

Table 1.

Data Panel Regression - Common Effect Model

\begin{tabular}{lllll}
\hline Variable & Coefficient & Std. Error & t-Statistic & Prob. \\
\hline C & 0.650011 & 0.097617 & 6.658790 & 0.0000 \\
Commissioners Board Size & 0.021899 & 0.008234 & 2.659577 & 0.0104 \\
Committee Audit Size & -0.004261 & 0.024877 & -0.371304 & 0.0046 \\
\hline R-squared & 0.241200 & & &
\end{tabular}

R-squared

Adjusted R-squared $\quad 0.182831$

Source: data processing results from Eviews

Commissioners Board Size has a regression coefficient of 0.021899 and probability of 0.0104 . Those numbers indicate that commissioners board size has a positive and significant effect on risk disclosure on mining companies under coal-mining sub-sector listed in IDX during the period of 2016-2018. This positive effect indicates that the bigger the size of commissioners board, the easier it is for supervision and management control to be conducted. The significant effect indicates that commissioners board size has an important role for the scope of the companies' risk disclosure. The bigger the commissioners board size, the bigger also the pressure put on management to widen the scope of information presented in their risk disclosures. This is because the role and function of commissioners board is to influence the management to widen the scope of their information disclosure in annual report in order to convince the stakeholders that management of the companies had already done the best possible actions and measures in favors of the stakeholders so that conflict of interests could be avoided.

A bigger commissioners board size indicates a better and more effective supervisions. Hence, management and stakeholders would be able to administer each other and thus preventing any information asymmetry. The result of this study is consistent with other previous studies, which also states that the size of commissioners board have a significant effect on risk disclosure. Audit Committee Size has a regression coefficient of -0.004261 and probability of 0.0046. Those numbers indicate that audit committee size has a negative and significant effect on risk disclosure on mining companies under coal-mining sub-sector listed in IDX during the period of 2016-2018. This negative effect indicates that the number of audit committee members impacts the scope of information disclosure regarding the risks faced by the company. The significant effect indicates that audit committee has a great influence on the scope of information in the companies' risk disclosure. This means the size of audit committee could influence the scope of information presented about the companies' risks. This is the result of the audit committee, that was formed by the commissioners board to help them in supervising and managing the companies, that had done their tasks and functions well, therefore the supervision would be better as the performance of audit committee gets better too.

The supervising role of the audit committee has previously been identified as an effective administration mechanism that helps the commissioners board in conducting their control and supervision. This supervising role of the audit committee has been identified as an effective supervision mechanism to help reduce agency cost and information asymmetry between management and the shareholders (Allegrini and Greco, 2013). Furthermore, the existence of audit committee has a main function as the party that maintain the quality of financial reporting (Haniffa and Cooke, 2002; Eng and Mak, 2003; Barakat and Hussainey, 2013). Apart from that, the other main function of audit committee is to maintain the balance and protect the interests of stakeholders, especially against any potentials of risks faced by the company in the future (Mangena and Pike, 2005). Zhang et al. (2013) also found in his study that audit committee has a significant effect on risk disclosure.

\section{Conclusions}

The result of this study concluded that the commissioners board size has a positive and significant effect on risk disclosure on mining companies under coal-mining sub-sector listed in IDX during the period of 2016-2018. Meanwhile, audit committee size has a negative and significant effect on risk disclosure on mining companies under coal-mining sub-sector listed in IDX during the period of 2016-2018. Future researchers who are interested in this topic could benefit from looking further into longer period of research years so that the results could be compared against previous studies, or to add or change the independent variables that affect risk disclosures in companies. Additionally, investors or prospective investors should take into consideration the companies' commissioners board size in their investment decision since it has a positive and significant effect on risk disclosure, based on the result of this study. 


\section{References}

Allegrini, M. and Greco, G. (2013) Corporate boards, audit committees and voluntary disclosure: Evidence from italian listed companies, Journal of Management \& Governance, 17(1): 187-216.

Viawa, C. A. (2019). Determinan Pengungkapan Resiko Pada Perusahaan Manufaktur Di Indonesia. E-Jra, 8(4) : 8998

Badan Pengawas Pasar Modal, (2004). Kep-29/PM/2004. Pembentukan dan Pedoman Kerja Komite Audit.

Barakat, A. and Hussainey, K. (2013) Bank governance, regulation, supervision, and risk reporting: Evidence from operational risk disclosures in european banks, International Review of Financial Analysis, 30: $254-273$.

Fadly, B. dan Simanjutak, E. (2019). Pengaruh Karakteristik Perusahaan Dan Mekanisme Corporate Governance Terhadap Pengungkapan Risiko Dalam Laporan Keuangan Interim Pada Perusahaan Pertambangan Yang Terdaftar Di Bursa Efek Indonesia. Jurnal Mutiara Akuntansi. 4(2): 34-44.

Ghozali, I. (2016). Aplikasi Analisis Multivariete Dengan Program IBM SPSS 23. Semarang : Badan Penerbit Universitas Diponegoro.

Gunawan, B. \& Zakiya, Y. N. (2017). Pengaruh Mekanisme Corporate Governance, Ukuran Perusahaan, Dan Leverage Terhadap Risk Management Disclosure, Ekspansi: Jurnal Ekonomi, Keuangan, Perbankan dan Akuntansi 9(1): 1-18

Haniffa, R.M. and Cooke, T.E. (2002) Culture, corporate governance and disclosure in malaysian corporations, Abacus, 38(3): 317-349

ICAEW. (2002). Reporting Business Risks : Meeting Expectations. London.

Ikatan Akuntan Indonesia. 2013. PSAK No. 60 Instrumen Keuangan: Pengungkapan. www.iaiglobal.or.id

Kencana, A. dan Lastanti, H. S. (2018). Pengaruh Good Corporate Governance Dan Karakteristik Perusahaan Terhadap Pengungkapan Risiko. Buku 2. Seminar Nasional Universitas Trisakti.

Linsley, P. M. \& Shrives. P. J. (2006). "Risk Reporting: A Study of Risk Disclosures in the Annual Reports of UK Companies". The British Accounting Review, 38(4) 387-404. DOI: 10.1016/j.bar.2006.05.002

Muslih, M., \& Mulyaningtyas, C. T. 2019. Pengaruh Corporate Governance, Kompetisi Dan Karakteristik Perusahaan Terhadap Pengungkapan Risiko Perusahaan. Jurnal Aset (Akuntansi Riset), 2(1): 146-155. DOI: https://doi.org/10.17509/jaset.v11i1.17303

Mangena, M. and Pike, R. (2005) 'The effect of audit committee shareholding, financial expertise and size on interim financial disclosures', Accounting and Business Research, 35(4): 327-349 .

Nathaniela, I., \& Badjuri, A. (2018). Faktor Yang Berpengaruh Terhadap Risk Disclosure (Studi Empiris Pada Perusahan Perbankan Yang Terdaftar Di Bursa Efek Indonesia Tahun 2015-2017). Dinamika Akuntansi, Keuangan Dan Perbankan, 7(2): 1-15.

Tarantika, R., \& Solikhah, B. (2019). Pengaruh Karakteristik Perusahaan, Karakteristik Dewan Komisaris Dan Reputasi Auditor Terhadap Pengungkapan Manajemen Risiko. Journal of Economic, Management, Accounting and Technology (JEMATech), 2(2): 142-155. DOI: https://doi.org/10.32500/jematech.v2i2.722

Setiawan, B. (2019). Pengaruh Tata Kelola Perusahaan Dan Struktur Kepemilikan Terhadap Tingkat Pengungkapan Risiko Keuangan. Jurnal Mitra Manajemen (JMM Online), 3(1): 1-12.

Sukrisno, A. dan Ardana, I.C. (2014). Etika Bisnis dan Profesi. Jakarta: Salemba Empat.

Sulistyaningsih, S., \& Gunawan, B., (2016). Analisis Faktor-Faktor Yang Memengaruhi Risk Management Disclosure (Studi Empiris Pada Perusahaan Manufaktur Yang Terdaftar Di Bursa Efek Indonesia Tahun 2012-2014), Riset Akuntansi dan Keuangan, 1(1): 1-11.

Syaefurakhman, B. \& Laksito, H. (2016). Faktor-Faktor Yang Mempengaruhi Pengungkapan Risiko (Studi Empiris Pada Perusahaan Manufaktur yang Terdaftar Di Bursa Efek Indonesia Tahun 2014). Journal Of Accounting, 5(4): 1-12.

Taures, N. S. I. (2011). Analisis Hubungan Antara Karakteristik Perusahaan Dengan Pengungkapan Risiko (Studi empiris pada laporan tahunan perusahaan-perusahaan nonkeuangan yang terdaftar di BEI tahun 2009). Thesis. Semarang : Universitas Diponegoro.

Tugiman, Hiro. (1995). Komite audit, PT. Eresco, Bandung

Utomo, Y. \& Chariri, A. (2014). Determinan Pengungkapan Risiko Pada Perusahaan Nonkeuangan Di Indonesia. Diponegoro Journal Of Accounting, 3(3): 1-14.

Wiagustini, N. L. P. (2010). Dasar-Dasar Manajemen Keuangan. Denpasar. Udayana University Press.

Zhang, X., Taylor, D., Qu, W. and Oliver, J. (2013) Corporate risk disclosures: Influence of institutional shareholders and audit committee, Corporate Ownership \& Control,10(4): 341-354 